Supporting Information

for

\title{
The Selective Preparation of an Aluminum Oxide and Its Isomeric C-H Activated Hydroxide
}

\author{
Hongping Zhu, ${ }^{\dagger}$ Jianfang Chai, ${ }^{\dagger}$ Vojtech Jancik, ${ }^{\dagger}$ Herbert W. Roesky, ${ }^{* \dagger}$ \\ William A. Merrill, ${ }^{*}$ and Philip P. Power ${ }^{\star}$ \\ ${ }^{\dagger}$ Institut für Anorganische Chemie der Georg-August Universität Göttingen, \\ Tammannstrasse 4, 37077 Göttingen, Germany \\ ${ }^{\ddagger}$ Department of Chemistry, University of California, Davis, \\ One Shields Avenue, Davis, California 95616, U.S.A.
}




\section{Experimental Section}

All manipulations were performed under a dry $\mathrm{N}_{2}$ atmosphere except for the reaction of LAl and $\mathrm{O}_{2}$ and using Schlenk line and glovebox techniques.

\section{(I). Synthesis of $[\mathrm{LAlO}]_{2}(1)$}

A toluene solution $(20 \mathrm{~mL})$ of LAl $(0.44 \mathrm{~g}, 1 \mathrm{mmol})$ in a Schlenk flask $(100 \mathrm{~mL})$ was cooled to $-78{ }^{\circ} \mathrm{C}$. The $\mathrm{N}_{2}$ atmosphere in the flask was exchanged to $\mathrm{O}_{2}\left(\mathrm{O}_{2}\right.$ gas was predried with $\left.\mathrm{P}_{4} \mathrm{O}_{10}\right)$. In the course of stirring and warming to room temperature the color of the solution slowly changed from red to orange, to yellow, and finally to almost colorless, and at ca. $-15{ }^{\circ} \mathrm{C}$ a colorless crystalline solid started to form from the solution. After additional stirring for $2 \mathrm{~h}$, the solvent was removed in vacuo and the residue was washed with $n$-hexane $(2 \mathrm{~mL})$ to give crystalline $\mathbf{1}$.

1: Yield: 0.37 g (80\%). M.p. $314-315^{\circ} \mathrm{C}$.

${ }^{1} \mathrm{H}$ NMR $\left(\mathrm{C}_{6} \mathrm{D}_{6}, 500.13 \mathrm{MHz}, 298 \mathrm{~K}, \mathrm{ppm}\right): \delta 0.22\left(\mathrm{~d},{ }^{3} J_{\mathrm{HH}}=6.7 \mathrm{~Hz}, 2 \times 3 \mathrm{H}, \mathrm{CHMe} 2\right)$, $1.07\left(\mathrm{~d},{ }^{3} J_{\mathrm{HH}}=6.7 \mathrm{~Hz}, 2 \times 3 \mathrm{H}, \mathrm{CHMe} 2\right), 1.21\left(\mathrm{~d},{ }^{3} J_{\mathrm{HH}}=6.7 \mathrm{~Hz}, 2 \times 3 \mathrm{H}, \mathrm{CHMe}\right), 1.27(\mathrm{~d}$, $\left.{ }^{3} J_{\mathrm{HH}}=6.7 \mathrm{~Hz}, 2 \times 3 \mathrm{H}, \mathrm{CHMe} e_{2}\right), 1.28\left(\mathrm{~d},{ }^{3} J_{\mathrm{HH}}=6.7 \mathrm{~Hz}, 2 \times 3 \mathrm{H}, \mathrm{CHMe}\right), 1.36(\mathrm{~s}, 2 \times 3 \mathrm{H}$, $\left.\beta-\mathrm{CH}_{3}\right), 1.39\left(\mathrm{~d},{ }^{3} J_{\mathrm{HH}}=6.7 \mathrm{~Hz}, 2 \times 3 \mathrm{H}, \mathrm{CHMe} 2\right), 1.45\left(\mathrm{~d},{ }^{3} J_{\mathrm{HH}}=6.7 \mathrm{~Hz}, 2 \times 3 \mathrm{H}, \mathrm{CHMe} e_{2}\right)$, $1.49\left(\mathrm{~d},{ }^{3} J_{\mathrm{HH}}=6.7 \mathrm{~Hz}, 2 \times 3 \mathrm{H}, \mathrm{CHMe} e_{2}\right), 1.52\left(\mathrm{~s}, 2 \times 3 \mathrm{H}, \beta-\mathrm{CH}_{3}\right), 2.63\left(\mathrm{sept},{ }^{3} J_{\mathrm{HH}}=6.7\right.$ $\mathrm{Hz}, 2 \times 1 \mathrm{H}, \mathrm{CHMe} 2), 3.22\left(\mathrm{sept},{ }^{3} J_{\mathrm{HH}}=6.7 \mathrm{~Hz}, 2 \times 1 \mathrm{H}, \mathrm{CHMe}\right), 3.57\left(\mathrm{sept},{ }^{3} J_{\mathrm{HH}}=6.7\right.$ $\mathrm{Hz}, 2 \times 1 \mathrm{H}, \mathrm{CHMe}$ ), $3.83\left(\mathrm{sept},{ }^{3} J_{\mathrm{HH}}=6.7 \mathrm{~Hz}, 2 \times 1 \mathrm{H}, \mathrm{CHMe}\right.$ ), $4.71(\mathrm{~s}, 2 \times 1 \mathrm{H}, \gamma-\mathrm{CH})$, 6.98-7.10, 7.15-7.31 (m, 12H, Ar- $\left.\mathrm{C}_{6} \mathrm{H}_{3}\right)$.

${ }^{13} \mathrm{C}$ NMR $\left(\mathrm{C}_{6} \mathrm{D}_{6}, 125.8 \mathrm{MHz}, 298 \mathrm{~K}, \mathrm{ppm}\right): \delta 22.2,23.4,24.2,24.5,25.0,25.7,26.4,26.8$, 27.2, 27.7, 29.1, 31.5, $32.4\left(C \mathrm{CHMe} 2\right.$ and $\left.\beta-\mathrm{CH}_{3}\right), 71.4\left(C \mathrm{HMe}_{2}\right), 97.8(\gamma-C), 122.7,124.2$, $125.3,125.7,126.9,127.7,128.9,142.0,143.7,145.7,146.2,148.1\left(\mathrm{Ar}-\mathrm{C}_{6} \mathrm{H}_{3}\right), 168.1$ $(C \mathrm{~N})$.

MS (EI) (m/z (\%)): $920.4(30)\left[M^{+}\right], 403.3(100)[\mathrm{L}-\mathrm{Me}]$. 
Elemental analysis calcd for $\mathrm{C}_{58} \mathrm{H}_{82} \mathrm{Al}_{2} \mathrm{~N}_{4} \mathrm{O}_{2}$ (921.29) (\%): C 75.62, H 8.97, N 6.08; found C 75.20, H 9.02, N 6.21.

X-ray quality crystals of $\mathbf{1}$ were obtained by keeping the hot toluene solution of $\mathbf{1}$ at room temperature for $24 \mathrm{~h}$.

\section{(II). An approach to 1 by using $[\mathrm{LAICl}(\mu-\mathrm{OH})]_{2}$ as a precursor}

More recently, we isolated compound $[\mathrm{LAlCl}(\mu-\mathrm{OH})]_{2}$ from the stepwise hydrolysis of LAlClI in the presence of $N$-heterocyclic carbene (abbreviated as :C) as hydrogen halide acceptor. $^{14}$ This compound has a dimeric structure with $\mathrm{Al}-\mathrm{Cl}$ and $\mathrm{Al}-\mu-\mathrm{OH}$ functionalities. Therefore, further treatment of this compound with two equiv of :C functioning as a $\mathrm{HCl}$ acceptor in an attempt to approach $\mathbf{1}$, or alternatively by the addition of $n \mathrm{BuLi}$ to eliminate $\mathrm{LiCl}$ and $n \mathrm{BuH}$ to the same target was not successful. The former resulted in no reaction and the latter led to an intractable mixture of products which was indicated by the EI mass spectrum and proton NMR analysis. This may indicate that, due to the considerably structural crowding of $\mathbf{1}$, this approach is not energetically favorable.

\section{(III). Synthesis of $2 \cdot 1.5 n$-hexane}

To a suspension of $1(0.38 \mathrm{~g}, 0.4 \mathrm{mmol})$ in toluene $(30 \mathrm{~mL})$ one equiv of $\mathrm{H}_{2} \mathrm{O}(7.2 \mu \mathrm{L}, 0.4$ mmol) was added at $0{ }^{\circ} \mathrm{C}$. The mixture was allowed to warm to room temperature and stirred for $12 \mathrm{~h}$ to give a clear solution. All volatiles were removed and the residue was recrystallized in toluene $/ n$-hexane at $-26^{\circ} \mathrm{C}$. The colorless crystals of $2 \cdot 1.5 n$-hexane were obtained (yield: $0.16 \mathrm{~g}, 40 \%$ ) and determined by X-ray structural analysis. The cell parameters are almost the same as those for $\mathbf{2} \cdot n$-hexane $\cdot 0.5$ toluene. ${ }^{11 \mathrm{e}} \mathbf{2} \cdot 1.5 n$-hexane: $a=13.677(1), b=21.289(1), c=23.014(1) \AA, \beta=104.69(1)^{\mathrm{o}}, V=6482(1) \AA^{3} ; 2 \cdot n-$ hexane $\cdot 0.5$ toluene: $a=13.731(3), b=21.352(4), c=22.877(5) \AA, \beta=103.58(3)^{\circ}, V=$ $6520(1) \AA^{3}$. 


\section{(IV). NMR measurement of 1}

When the NMR tube sample of $\mathbf{1}$ was kept at room temperature for one month, the

corresponding ${ }^{1} \mathrm{H}$ and ${ }^{13} \mathrm{C}$ NMR spectral analysis showed that the resonances at high field (one septet and one doublet) disappeared, while the data could be assigned to $2^{11 \mathrm{e}}$ including a small amount of free LH (the chemical shifts and the integral intensities are in good agreement with those analyzed for compound $\mathbf{2}$ except for those of one molecule of toluene and small amounts of free LH). This implies a transformation of $\mathbf{1}$ to $\mathbf{2}$ due to the possible penetration of small amounts of moisture into the sample through the seal.

(V). Synthesis of $\left\{\mathrm{HC}[(\mathrm{CMe})(\mathrm{NAr})]\left[(\mathrm{CMe})\left(\mathrm{N}-\mathrm{C}_{6} \mathrm{H}_{3}-2-i \mathrm{Pr}-6-\mathrm{CH}\left(\mathrm{CH}_{2}\right)(\mathrm{Me})\right]\right\} \mathrm{Al}(\mathrm{NHAr} ")\right.$ (3), $\left[\left\{\mathrm{HC}[(\mathrm{CMe})(\mathrm{NAr})]\left[(\mathrm{CMe})\left(\mathrm{N}-\mathrm{C}_{6} \mathrm{H}_{3}-2-i \operatorname{Pr}-6-\mathrm{CH}\left(\mathrm{CH}_{2}\right)(\mathrm{Me})\right]\right\} \mathrm{Al}(\mu-\mathrm{OH})\right]_{2}\right.$ and $\mathrm{H}_{2} \mathrm{NAr}$ ', (5)

Pre-cooled toluene $(35 \mathrm{~mL})$ was added to a mixture of LAl $(0.47 \mathrm{~g}, 1.07 \mathrm{mmol})$ and $\mathrm{N}_{3} \mathrm{Ar}^{\prime \prime}(0.38 \mathrm{~g}, 1.07 \mathrm{mmol})$ containing a very small amount of water at $-78{ }^{\circ} \mathrm{C}$ (The very small amount of water in $\mathrm{N}_{3} \mathrm{Ar}$ ', is detected by the IR spectrum: $v_{\mathrm{H} 2 \mathrm{O}} 3400$ (br, w) cm ${ }^{-1}$ ). The mixture was allowed to warm to room temperature and stirred for $12 \mathrm{~h}$. After workup, the solution was dried in vacuum and the residue was washed with $n$-hexane $(2 \mathrm{~mL})$ to afford a colorless crystalline solid. The melting point is $218-219^{\circ} \mathrm{C}$, however, the proton NMR spectrum indicates two sets of resonances. By recrystallization in $n$-hexane/toluene, compounds 3 and $\mathbf{4}$ are isolated one by one both as colorless crystals. After the collection of crystals of 4 , the mother liquor was kept at $4{ }^{\circ} \mathrm{C}$ for three weeks. A small amount of colorless crystals of $\mathbf{5}$ was obtained and collected by filtration.

3: yield: 0.26 g. M.p. $194-195^{\circ} \mathrm{C}$. 
${ }^{1} \mathrm{H}$ NMR $\left(300.13 \mathrm{MHz}, \mathrm{C}_{6} \mathrm{D}_{6}, 298 \mathrm{~K}\right): \delta-0.94\left(\mathrm{dd}, 1 \mathrm{H},{ }^{2} J_{\mathrm{HH}}=-15.1 \mathrm{~Hz},{ }^{3} J_{\mathrm{HH}}=7.7 \mathrm{~Hz}\right.$, Al- $\left.\mathrm{CH}_{2}\right),-0.19\left(\mathrm{dd}, 1 \mathrm{H},{ }^{2} J_{\mathrm{HH}}=-15.1 \mathrm{~Hz},{ }^{3} J_{\mathrm{HH}}=2.0 \mathrm{~Hz}, \mathrm{Al}-\mathrm{CH}_{2}\right), 0.66,0.90,0.97,1.14$, $1.18,1.19,1.22\left(\mathrm{~d}, 7 \times 3 \mathrm{H},{ }^{3} J_{\mathrm{HH}}=6.6 \mathrm{~Hz}, \mathrm{CH}\left(\mathrm{CH}_{3}\right)_{2}\right), 1.44,1.52\left(\mathrm{~s}, 2 \times 3 \mathrm{H}, \beta-\mathrm{CH}_{3}\right)$, $1.59,1.76,2.13,2.19,2.25,2.34\left(\mathrm{~s}, 6 \times 3 \mathrm{H}, \mathrm{Ar}{ }^{\prime}{ }^{-}-M e\right), 2.50,2.79,3.33\left(\mathrm{sept}, 3 \times 1 \mathrm{H},{ }^{3} J_{\mathrm{HH}}\right.$ $\left.=6.6 \mathrm{~Hz}, \mathrm{CH}\left(\mathrm{CH}_{3}\right)_{2}\right), 3.04\left(\mathrm{~m}, 1 \mathrm{H}, \mathrm{CH}\left(\mathrm{CH}_{3}\right)\left(\mathrm{CH}_{2}\right)\right), 3.47(\mathrm{~s}, 1 \mathrm{H}, \mathrm{NH}), 4.83(\mathrm{~s}, 1 \mathrm{H}, \gamma-$ $\mathrm{CH}), 6.62-7.20(\mathrm{~m}, 13 \mathrm{H}, \mathrm{Ar}-H)$.

${ }^{13} \mathrm{C}$ NMR (125.76 MHz, $\left.\mathrm{C}_{6} \mathrm{D}_{6}, 298 \mathrm{~K}\right): \delta 20.25,21.06,21.13,21.17,22.16,22.25,23.00$, $24.31,24.77,24.83,24.84,24.95,25.13,26.05,26.90,27.66,28.08,28.72,31.91,40.37$ $\left(\beta-\mathrm{CH}_{3}, \mathrm{CH}\left(\mathrm{CH}_{3}\right)_{2}, \mathrm{CH}\left(\mathrm{CH}_{3}\right)\left(\mathrm{CH}_{2}\right), \mathrm{Ar}{ }^{\prime}{ }^{-} \mathrm{Me}\right), 98.66(\gamma-\mathrm{CH}), 116.28,118.60,124.64$, $124.72,125.22,127.43,129.00,129.40,136.88,137.04,140.46,141.46,144.44,144.80$, 146.06, 146.27, 148.89 (Ar-C), 131.2 (br, Al-C), $169.97(C \mathrm{~N})$.

IR (KBr plate, Nujol mull): $v_{\mathrm{NH}}=3265 \mathrm{~cm}^{-1}$.

EI-MS: $m / z(\%): 771.7\left(10,\left[M^{+}\right]\right), 443.4\left(100,\left[M^{+}-\right.\right.$NHAr' - 1].

Elemental analysis (\%) calcd. for $\mathrm{C}_{53} \mathrm{H}_{66} \mathrm{AlN}_{3}$ : C 82.45, H 8.62, N 5.44. Found: C 82.32, H 8.55, N 5.51.

4: yield: 0.19 g. M.p. $333-335^{\circ} \mathrm{C}$.

${ }^{1} \mathrm{H}$ NMR (300.13 MHz, $\left.\mathrm{C}_{6} \mathrm{D}_{6}, 298 \mathrm{~K}\right): \delta-1.69\left(\mathrm{t}, 1 \mathrm{H},{ }^{2} J_{\mathrm{HH}}=-14.2 \mathrm{~Hz},{ }^{3} J_{\mathrm{HH}}=14.2 \mathrm{~Hz}\right.$, Al- $\left.\mathrm{CH}_{2}\right),-0.35\left(\mathrm{dd}, 1 \mathrm{H},{ }^{2} J_{\mathrm{HH}}=-14.2 \mathrm{~Hz},{ }^{3} J_{\mathrm{HH}}=3.5 \mathrm{~Hz}, \mathrm{Al}-\mathrm{CH}_{2}\right), 0.29(\mathrm{~s}, 2 \times 1 \mathrm{H}, \mathrm{OH})$, $0.74,0.86,0.90,1.03,1.17,1.28,1.32\left(\mathrm{~d}, 7 \times 3 \mathrm{H},{ }^{3} J_{\mathrm{HH}}=6.6 \mathrm{~Hz}, \mathrm{CH}\left(\mathrm{CH}_{3}\right)_{2}\right), 1.42,1.59$ (s, $\left.2 \times 3 \mathrm{H}, \beta-\mathrm{CH}_{3}\right), 2.47,2.78,2.99$ (sept, 3 x $\left.1 \mathrm{H},{ }^{3} J_{\mathrm{HH}}=6.6 \mathrm{~Hz}, \mathrm{CH}\left(\mathrm{CH}_{3}\right)_{2}\right), 2.60(\mathrm{~m}, 1$ $\left.\mathrm{H}, \mathrm{CH}\left(\mathrm{CH}_{3}\right)\left(\mathrm{CH}_{2}\right)\right), 4.93(\mathrm{~s}, 1 \mathrm{H}, \gamma-\mathrm{CH}), 6.80-7.20(\mathrm{~m}, 12 \mathrm{H}, \mathrm{Ar}-H)$.

${ }^{13} \mathrm{C}$ NMR (125.76 MHz, $\left.\mathrm{C}_{6} \mathrm{D}_{6}, 298 \mathrm{~K}\right): \delta 20.59,20.87,21.26,21.90,22.44,22.89,24.06$, $24.33,24.97,25.42,26.60,26.89,28.37,28.53,31.91,33.79\left(\beta-\mathrm{CH}_{3}, \mathrm{CH}\left(\mathrm{CH}_{3}\right)_{2}\right.$, $\left.\mathrm{CH}\left(\mathrm{CH}_{3}\right)\left(\mathrm{CH}_{2}\right)\right), 100.09(\gamma-\mathrm{CH}), 116.55,123.91,124.68,126.88,127.81,132.10,141.46$, 143.29, 144.11, 145.52, 146.16, 148.30 (Ar-C), 134.2 (br, Al-C), $168.11(C \mathrm{~N})$.

IR (KBr plate, Nujol mull): $v_{\mathrm{OH}}=3400(\mathrm{br}) \mathrm{cm}^{-1}$. 
EI-MS: $m / z(\%): 920.4\left(2,\left[M^{+}\right]\right), 887.4\left(100,\left[M^{+}-2 \mathrm{Me}-2 \mathrm{H}-1\right]\right.$.

Elemental analysis (\%) calcd. for $\mathrm{C}_{58} \mathrm{H}_{80} \mathrm{AlN}_{4} \mathrm{O}_{2}$ : C 75.62, H 8.97, N 6.08. Found: $\mathrm{C}$ 75.48, H 8.85, N 6.11.

5: ${ }^{1} \mathrm{H}$ NMR (500.13 MHz, $\left.\mathrm{C}_{6} \mathrm{D}_{6}, 298 \mathrm{~K}\right): \delta 1.35$ (s, br, $\left.2 \mathrm{H}, \mathrm{NH}_{2}\right), 2.06$ (s, 4 x 3 H, o-Ar' Me), 2.20 (s, 2 x 3 H, p-Ar'’-Me), 6.84-6.87, 7.07-7.10 (m, 7 H, Ar-H).

${ }^{13} \mathrm{C}$ NMR (125.76 MHz, C6 $\left.\mathrm{D}_{6}, 298 \mathrm{~K}\right): \delta 20.53$ (o-Ar'”-Me), 21.19 (p-Ar'”-Me), 128.88, $129.03,130.26,135.33,136.43,137.17,142.53,147.95(\operatorname{Ar}-C)$.

IR (KBr plate, Nujol mull): $v_{\mathrm{NH}}=3384,3481 \mathrm{~cm}^{-1}$.

Correct elemental analysis.

Note: This reaction is reproducible. The repetition of this reaction affords the same products, as is confirmed by the NMR measurement. Moreover, the X-ray structural analyses of crystals of $\mathbf{4}$ obtained from the respective reactions give the same result.

\section{(VI). The structural determination of $1,3 \cdot 0.12$ toluene $\cdot 0.05 n$-hexane, and 4}

The structures of $1,3 \cdot 0.12$ toluene $\cdot 0.05 n$-hexane, and 4 were solved by direct methods (SHELXS-97) and refined with all data by full-least-squares against $F^{2}$. The non-hydrogen atoms were located by difference Fourier synthesis and refined anisotropically except for one carbon atom of $n$-hexane in $3 \cdot 0.12$ toluene $\cdot 0.05 n$-hexane which was refined isotropically. In 1, one isopropyl group was disordered and located at two positions with an occupation ratio of $0.56 / 0.44$, and the hydrogen atoms except for $\mathrm{H}(3 \mathrm{~A})$ were included in geometrically idealized positions. Localization of the $\gamma-\mathrm{CH}(3 \mathrm{~A})$ hydrogen from the electron density map proved to be more accurate than its fixing in the idealized position and led to lowering of the $R 1$ and w $R 2$ values. In $3 \cdot 0.12$ toluene $\cdot 0.05 n$-hexane, 0.12 toluene and $0.05 n$-hexane were sharing the same non fully occupied special position. This position occupied $34 \%$ of space which was shared with two molecules of 3 , and therefore contained $24 \%$ of toluene and $10 \%$ of $n$-hexane. Both solvents were disordered over two positions. The hydrogen atoms were 
included in geometrically idealized positions except for that of Al-NH which was located by difference Fourier synthesis. In $\mathbf{4}$, one $i \operatorname{Pr}$ bound to $\mathrm{Al}(2)$ was disordered over two positions with an occupation ratio of $0.90 / 0.10$. The hydrogen atoms were included in geometrically idealized positions except for those of $\mathrm{Al}-\mathrm{OH}$ which were located by difference Fourier synthesis. The $U$ iso for all hydrogen atoms were tied to the $U$ iso of the parent atoms and were refined with the riding model, except for those of the methyl groups of the disordered $i \operatorname{Pr}$ group in $\mathbf{1}$ and those of solvents in $\mathbf{3} \cdot 0.12$ toluene $\cdot 0.05 n$-hexane, where the riding model was not applied. In addition, the usage of the $\mathrm{Cu}$ radiation does not allow data collection to atomic resolution of $0.84 \AA$, but just to that of $0.9 \AA$. Therefore, the $2 \theta$ range caused by the diffractometer is too low. However it does not affect the clear determination of the molecular structure. In the structure of $3 \cdot 0.12$ toluene $\cdot 0.05 n$-hexane, the low occupancy of $n$-hexane molecule as well as its disorder over two positions does not allow better refinement of the $n$ hexane. Thus the carbon atoms in $n$-hexane are refined just isotropically and the molecule is close to the main one. This cannot be further improved.

(VII). Crystal data and structure refinement for $1,3 \cdot 0.12$ toluene $\cdot 0.05 n$-hexane, and 4

\begin{tabular}{ll} 
Compound & \multicolumn{1}{c}{$\mathbf{1}$} \\
formula & $\mathrm{C}_{58} \mathrm{H}_{82} \mathrm{Al}_{2} \mathrm{~N}_{4} \mathrm{O}_{2}$ \\
fw & 921.24 \\
crystal system & Monoclinic \\
space group & $P 2(1) / n$ \\
temp, K & $100(2)$ \\
$\lambda, \AA$ & 1.54178 \\
$a, \AA$ & $13.652(3)$ \\
$b, \AA$ & $13.717(3)$ \\
$c, \AA$ & $14.166(3)$ \\
$a$, deg & 90 \\
$\beta$, deg & $106.89(3)$ \\
$\gamma$, deg & 90
\end{tabular}




\begin{tabular}{|c|c|}
\hline$V, \AA^{3}$ & $2538(1)$ \\
\hline$Z$ & 2 \\
\hline$\rho_{\text {calcld., }}$ g.cm ${ }^{-3}$ & 1.205 \\
\hline$\mu, \mathrm{mm}^{-1}$ & 0.867 \\
\hline$F(000)$ & 1000 \\
\hline crystal size, $\mathrm{mm}^{3}$ & $0.15 \times 0.10 \times 0.03$ \\
\hline$\theta$ range for data collection, deg & 3.96 to 58.95 \\
\hline \multirow[t]{3}{*}{ index ranges } & $-14 \leq h \leq 15$ \\
\hline & $-14 \leq k \leq 14$ \\
\hline & $-15 \leq l \leq 15$ \\
\hline no. of reflns collected & 14090 \\
\hline no. of indep. reflns $\left(R_{\text {int }}\right)$ & $3617(0.0295)$ \\
\hline no. of data / restraints / parameters & $3617 / 141 / 337$ \\
\hline GoF on $F^{2}$ & 1.049 \\
\hline$R 1^{\mathrm{a}}{ }^{\mathrm{a}} w R 2^{\mathrm{b}}(I>2 \sigma(I))$ & $0.0328,0.0851$ \\
\hline$R 1,{ }^{\mathrm{a}} w R 2^{\mathrm{b}}$ (all data) & $0.0364,0.0878$ \\
\hline largest diff. peak / hole, e. $\AA^{-3}$ & $0.330 /-0.257$ \\
\hline \multicolumn{2}{|c|}{${ }^{\mathrm{a}} R=\mathrm{S}|| F_{\mathrm{o}}|-| F_{\mathrm{c}}|| \mathrm{S}\left|F_{\mathrm{o}}\right| \cdot{ }^{\mathrm{b}} w R 2=\left[\mathrm{S} w\left(F_{\mathrm{o}}{ }^{2}-F_{\mathrm{c}}{ }^{2}\right)^{2} / \mathrm{S} w\left(F_{\mathrm{o}}{ }^{2}\right)^{2}\right]^{1 / 2}$} \\
\hline Compound & $3 \cdot 0.12$ toluene $\cdot 0.05 n$-hexane \\
\hline formula & $\mathrm{C}_{54.14} \mathrm{H}_{67.65} \mathrm{AlN}_{3}$ \\
\hline fw & 787.44 \\
\hline crystal system & Monoclinic \\
\hline space group & $C 2 / c$ \\
\hline temp, $\mathrm{K}$ & $100(2)$ \\
\hline$\lambda, \AA$ & 1.54178 \\
\hline$a, \AA$ & $21.560(4)$ \\
\hline$b, \AA$ & $10.457(2)$ \\
\hline$c, \AA$ & $40.816(8)$ \\
\hline$\alpha, \operatorname{deg}$ & 90 \\
\hline$\beta, \operatorname{deg}$ & $97.26(3)$ \\
\hline$\gamma, \operatorname{deg}$ & 90 \\
\hline$V, \AA^{3}$ & 9128(3) \\
\hline$Z$ & 8 \\
\hline
\end{tabular}




\begin{tabular}{|c|c|}
\hline$\rho_{\text {calcld. }}$, g. $\mathrm{cm}^{-3}$ & 1.146 \\
\hline$\mu, \mathrm{mm}^{-1}$ & 0.670 \\
\hline$F(000)$ & 3412 \\
\hline crystal size, $\mathrm{mm}^{3}$ & $0.20 \times 0.10 \times 0.10$ \\
\hline$\theta$ range for data collection, deg & 2.18 to 59.07 \\
\hline \multirow[t]{3}{*}{ index ranges } & $-23 \leq h \leq 23$ \\
\hline & $-11 \leq k \leq 11$ \\
\hline & $-45 \leq l \leq 43$ \\
\hline no. of reflns collected & 30396 \\
\hline no. of indep. reflns $\left(R_{\text {int }}\right)$ & $6498(0.0374)$ \\
\hline no. of data / restraints / parameters & $6498 / 126 / 624$ \\
\hline GoF on $F^{2}$ & 1.023 \\
\hline$R 1,{ }^{\mathrm{a}} w R 2^{\mathrm{b}}(I>2 \sigma(I))$ & $0.0369,0.0859$ \\
\hline$R 1,{ }^{\mathrm{a}} w R 2^{\mathrm{b}}$ (all data) & $0.0463,0.0910$ \\
\hline largest diff. peak / hole, e. $\AA^{-3}$ & $0.200 /-0.265$ \\
\hline \multicolumn{2}{|c|}{${ }^{\mathrm{a}} R=\mathrm{S}|| F_{\mathrm{o}}|-| F_{\mathrm{c}}|| / \mathrm{S}\left|F_{\mathrm{o}}\right| \cdot{ }^{\mathrm{b}} w R 2=\left[\mathrm{S} w\left(F_{\mathrm{o}}{ }^{2}-F_{\mathrm{c}}{ }^{2}\right)^{2} / \mathrm{S} w\left(F_{\mathrm{o}}{ }^{2}\right)^{2}\right]^{1 / 2}$} \\
\hline Compound & 4 \\
\hline formula & $\mathrm{C}_{58} \mathrm{H}_{82} \mathrm{Al}_{2} \mathrm{~N}_{4} \mathrm{O}_{2}$ \\
\hline fw & 921.24 \\
\hline crystal system & Monoclinic \\
\hline space group & $P 2 / c$ \\
\hline temp, $\mathrm{K}$ & $100(2)$ \\
\hline$\lambda, \AA$ & 1.54178 \\
\hline$a, \AA$ & $22.605(4)$ \\
\hline$b, \AA$ & $12.583(2)$ \\
\hline$c, \AA$ & $19.132(3)$ \\
\hline$\alpha, \operatorname{deg}$ & 90 \\
\hline$\beta$, deg & $102.68(2)$ \\
\hline$\gamma, \operatorname{deg}$ & 90 \\
\hline$V, \AA^{3}$ & $5310(2)$ \\
\hline$Z$ & 4 \\
\hline$\rho_{\text {calcld., }}$ g.cm ${ }^{-3}$ & 1.153 \\
\hline$\mu, \mathrm{mm}^{-1}$ & 0.829 \\
\hline
\end{tabular}




$\begin{array}{ll}F(000) & 2000 \\ \text { crystal size, } \mathrm{mm}^{3} & 0.10 \times 0.05 \times 0.05 \\ \theta \text { range for data collection, deg } & 3.51 \text { to } 58.97 \\ \text { index ranges } & -23 \leq h \leq 24 \\ & -13 \leq k \leq 13 \\ & -21 \leq l \leq 20 \\ \text { no. of reflns collected } & 28366 \\ \text { no. of indep. reflns }\left(R_{\text {int }}\right) & 7554(0.0360) \\ \text { no. of data / restraints } / \text { parameters } & 7554 / 97 / 654 \\ \text { GoF on } F^{2} & 1.025 \\ R 1,{ }^{\mathrm{a}} w R 2^{\mathrm{b}}(I>2 \sigma(I)) & 0.0344,0.0850 \\ R 1^{\mathrm{a}}{ }^{\mathrm{a}} w R 2^{\mathrm{b}}(\text { all data }) & 0.0421,0.0895 \\ {\text { largest diff. peak } / \text { hole, e. } \AA^{-3}}_{{ }^{\mathrm{a}} R=\Sigma|| F_{\mathrm{o}}|-| F_{\mathrm{c}} \| / \Sigma\left|F_{\mathrm{o}}\right| .{ }^{\mathrm{b}} w R 2=\left[\Sigma w\left(F_{\mathrm{o}}{ }^{2}-F_{\mathrm{c}}{ }^{2}\right)^{2} / \Sigma w\left(F_{\mathrm{o}}{ }^{2}\right)^{2}\right]^{1 / 2}}\end{array}$

\section{(VIII). Molecular structure of 3}

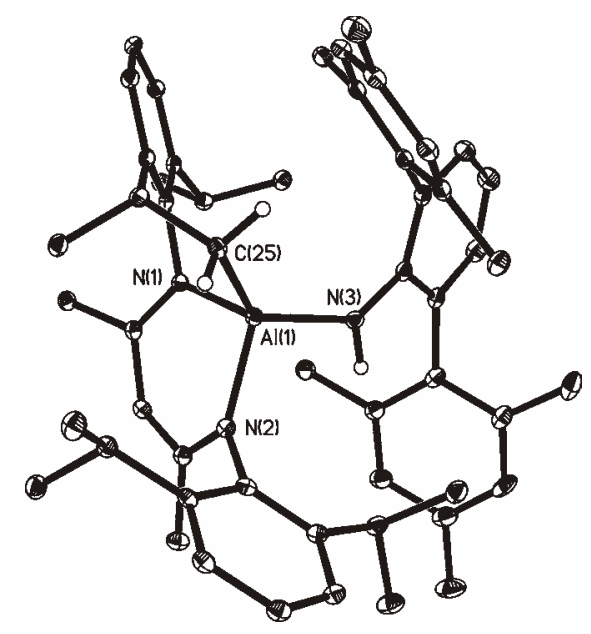

Figure 3. Molecular structure of 3 (30\% probability thermal ellipsoids). Selected bond lengths $(\AA)$ and angles $\left({ }^{\circ}\right)$ : $\mathrm{Al}(1)-\mathrm{N}(1)$ 1.930(1), $\mathrm{Al}(1)-\mathrm{N}(2)$ 1.926(2), $\mathrm{Al}(1)-\mathrm{N}(3)$ 1.840(1), $\mathrm{Al}(1)-\mathrm{C}(25)$ 1.967(2), C(25)-C(24) 1.555(2), N(1)-Al(1)-N(2) 98.12(6), N(1)-Al(1)-N(3) 113.83(6), N(2)-Al(1)-N(3) 101.98(7), N(3)-Al(1)-C(25) 124.18(7). 